\title{
Fuzzy-based methodological proposal for participatory diagnosis in the linear parks management
}

\author{
Adriano Bressane $^{\mathrm{a}, *}$, Carlos Humberto Biagolini ${ }^{\mathrm{a}}$, Patricia Satie Mochizuki ${ }^{\mathrm{b}}$, \\ José Arnaldo Frutuoso Roveda ${ }^{\mathrm{a}}$, Roberto Wagner Lourenço ${ }^{\mathrm{a}}$ \\ a São Paulo State University (Unesp), Institute of Science and Technology, Environmental Sciences Graduate Program, Campus at Sorocaba city, 03 March Avenue, 511, \\ Brazil \\ b Secretariat of Environment of the State of São Paulo, Biodiversity and Natural Resources Coordination, Regional at Sorocaba city, Gustavo Teixeira Street, 412, Brazil
}

\section{A R T I C L E I N F O}

\section{Keywords:}

Participatory decision-making

Knowledge-based system

Community engagement

\begin{abstract}
A B S T R A C T
Participatory decision-making in the management of linear parks can provide better outcomes than classical topdown procedures. However, the integration of technical knowledge with the understanding of the community requires an approach able to deal with uncertainty, due to the issues of vagueness and subjectivity. Therefore, the present paper introduces a fuzzy-based proposal for supporting participatory diagnosis. For this purpose, five Mamdani-type systems were built based on the knowledge of experts, including as indicators the species richness of fauna and flora, land cover, basic and recreational facilities, support services, and the park users' perceptions. By integrating such indicators, three indexes were obtained for assessing the natural condition, infrastructure, and functional performance of a linear park. The proposed system was then applied in a case study of the Tiquatira linear park in São Paulo city, Brazil. The results indicated that the park has high functional performance, but that improvements in its natural condition and infrastructure are needed, such as the reclamation of disturbed areas and ongoing maintenance of the facilities. The use of fuzzy modeling enabled integration of the technical assessment by experts and the users' perception, in order to support a participatory diagnosis taking into account the existing uncertainties. In conclusion, this fuzzy-based proposal can be considered a promising approach for the participatory management of linear parks. In future studies, techniques for the case-by-case weighting of variables could be assessed, in order to strengthen the systems described in the present paper.
\end{abstract}

\section{Introduction}

Significant decreases of green spaces have occurred as a consequence of urban sprawl and the increase of built-up areas, with negative impacts on environmental resources, habitat and biodiversity, human health, and the quality of life in cities (Alberti, 2010; Jamwal et al., 2008; Ilstedt et al., 2007; Evans et al., 2006; Cornelis and Hermy, 2004; Melles et al., 2003; Jim and Chen, 2002). One possible strategy to help mitigate such problems is the implementation of multifunctional linear parks, which represent a sustainable solution in the urban landscape (Tan, 2006; Turner, 2006; Conine et al., 2004).

Linear parks can provide nature conservation and environmental services, while at the same time contributing to property appreciation, recreational opportunities, aesthetic quality, and cultural identity, hence improving the sustainability of the urban environment (Giordano and Riedel, 2008; Bryant, 2006; Godbey et al., 2005; et al., 2004Frischenbruder and Pellegrino, 2004; Morancho, 2003; Cook,
2002; Thompson, 2002; Bruner et al., 2001).

The conservation and performance of linear parks is influenced by the users' behavior and community engagement, so the use of participatory decision-making in their management can provide better outcomes than the classical top-down approach (Etienne et al., 2011; Reed, 2008; Fraser et al., 2006; Robertson and Lawes, 2005; Colfer, 2005; Sandström et al., 2003; Twyman, 2000; Ostrom et al., 1999).

Various tools have been developed to encourage and improve the involvement of community members in environmental management, among which are communitarian biomaps (Bressane et al., 2011), pebble distributions (Sheil and Liswanti, 2007), the scenarios method (Peterson et al., 2003), spider diagrams (Lynam, 2001), who counts matrices (Colfer et al., 1999), and Venn diagrams (Pretty et al., 1995). Important tools based on mathematical modeling include multi-criteria decision analysis (Myllyviita et al., 2011), hierarchical analysis (Hujala and Kurttila, 2010), bayesian belief networks (Sayer and Campbell, 2004), and metagame theory (Jeffers, 1997). However, despite success-

\footnotetext{
* Corresponding author at: 03 March Avenue, 511, Alto da Boa, Sorocaba city, São Paulo State, Brazil.

E-mail address: adriano.bressane@posgrad.sorocaba.unesp.br (A. Bressane).
} 
ful efforts to empower society and stimulate its involvement, there are still issues to overcome, such as integrating technical knowledge with community understanding (Stoll-Kleemann and Welp, 2008; Lynam et al., 2007; Kellert et al., 2000).

As an alternative strategy, fuzzy modeling provides a logical approach able to deal with uncertainty and match different measures, using linguistic values to simulate human reasoning (Bressane et al., 2016; Liu and Zhou, 2012; Canavese et al., 2012; Janssen et al., 2010; Warmink et al., 2010; Liu et al., 2010; Lermontov et al., 2009; Ascough et al., 2008; Zadeh, 2008; Icaga, 2007; Onkal-Engin et al., 2004; Adriaenssens et al., 2004; Silvert, 2000).

Fuzzy theory was formalized in the mid-1960s from an extension of classical theory, in order to deal with complex phenomena and especially to provide a suitable mathematical treatment for processes involving fuzziness, where uncertainties arise due to issues such as vagueness and subjectivity (Pedrycz and Gomide, 2007; Zadeh, 2008; Zadeh, 1965). Notwithstanding, the fuzzy-based methods became popular after the 1980s, being employed in many applications.

Silvert (2000) described the construction of environmental indices, highlighting fuzzy modeling as a simple and powerful approach whose formalism enables the integration of different kinds of variables and the ability to deal with missing data. In a study of models applied to decision-making in ecosystems management, Adriaenssens et al. (2004) considered that fuzzy rule-based systems offer an approach capable of processing uncertain knowledge or data, providing a user-friendly modeling structure.

Due to the need for interpretability and transparency, and given the intrinsic fuzziness of environmental issues, the use of fuzzy models to support management systems is becoming increasingly common (Lermontov et al., 2009; Ascough et al., 2008). The most frequent environmental applications of the fuzzy approach include its use in impact assessments (Shepard, 2005), indices of urban air quality (Onkal-Engin et al., 2004), and water quality evaluations (Liu and Zhou, 2012; Liu et al., 2010; Lermontov et al., 2009; Icaga, 2007).

In a review of the literature on research using the fuzzy approach, Canavese et al. (2012) highlighted its ability to incorporate the knowledge and judgment of experts, and thus to provide support for the decision-making process. Exploring the ability to model human reasoning, Bressane et al. (2016) also used the fuzzy approach to include the population's perception in assessment of the impact of noise pollution on health. Moreover, the fuzzy approach enables "computing with words" (Zadeh, 2012), due to the mathematical treatment of linguistic attributes such as "good ecological conditions", which cannot be measured by standard methods.

The present study aims to introduce a fuzzy-based methodology to support participatory diagnosis in the management of urban linear parks, as an alternative for integrating the technical knowledge and community understanding, taking into account the uncertainties involved. In addition, the proposed approach was applied in a case study of the Tiquatira linear park in São Paulo (Brazil).

\section{Methodological proposal}

A knowledge-based system was developed for participatory diagnosis in the management of urban linear parks. The selection of variables, definition of functions, and establishment of the rules base were performed according to the knowledge of the experts (Fig. 1).

As recommended by Krueger et al. (2012), the experts were selected considering their relevant and extensive experience. Consultations were held with engineers, biologists, a geographer, and mathematicians with expertise in modeling applied to environmental monitoring and assessment. Thus, aspects of the natural condition and the infrastructure of linear parks were indicated as having important influences on functional performance.

For building a natural condition quality index $\left(Q_{N}\right)$, the land cover $\left(L_{\text {cov }}\right)$, species richness of fauna $\left(S_{\text {fau }}\right)$ and flora $\left(S_{\text {flo }}\right)$, which make up the technical assessment of the natural condition by experts $\left(T_{\text {nat }}\right)$, and users' perception $\left(U_{\text {nat }}\right)$ were defined as indicators. In turn, an infrastructure quality index $\left(Q_{\mathrm{I}}\right)$ was constructed using indicators based on the basic infrastructure $\left(B_{\text {inf }}\right)$, recreational infrastructure $\left(R_{\text {inf }}\right)$, and support services $\left(S_{\text {inf }}\right.$ ), which make up the technical assessment of the infrastructure by experts $\left(T_{\text {inf }}\right)$, and users' perception $\left(U_{\text {inf }}\right)$. Then, the integration of these indexes $\left(Q_{N}\right.$ and $\left.Q_{I}\right)$ provided a functional performance index $\left(F_{\mathrm{P}}\right)$ for participatory diagnosis in urban linear parks management. Thus, the indexes $Q_{\mathrm{N}}, Q_{\mathrm{I}}$, and $F_{\mathrm{P}}$ were obtained by means of hierarchical fuzzy inference systems (FIS), with several subsystems at different levels, as shown in Fig. 2.

As shown in Fig. 2, the proposed approach uses 5 fuzzy inference systems (FIS) based on 8 indicators ( $L_{\text {cov }}, S_{\text {flo }}, S_{\text {fau }}, U_{\text {nat }}, B_{\text {inf }}, R_{\text {inf }}, S_{\text {inf }}$, and $\left.U_{\text {inf }}\right)$ and 3 indexes $\left(Q_{N}, Q_{\mathrm{I}}\right.$, and $\left.F_{\mathrm{p}}\right)$. Hence, for supporting the participatory management of urban linear parks, the last system ( $\mathrm{FIS}_{5}$ ) results in a single value that enables classification of the park according to its functional performance $\left(F_{\mathrm{P}}\right)$, which is rated according to the value obtained, as follows: very low [0-12.5[, low [12.5-37.5[, regular [37.5-62.5[, high [62.5-87.5[, and very high [87.5-100].

Furthermore, a comparative analysis of the quality indexes given by intermediate systems ( $\mathrm{FIS}_{2}$ and $\mathrm{FIS}_{4}$ ) enables identification of whether the management measures should focus on improving the infrastructure, the natural condition, or both.

Regarding the infrastructure indicators, parameters were proposed to guide the technical assessment by the experts. The basic infrastructure $\left(B_{\text {inf }}\right)$ included parameters for the parking lot (automotive and bicycle stand), public toilets, night lighting, drinking fountain, and essential facilities (benches, wastebaskets, signposting, etc.). The recreational infrastructure $\left(R_{\text {inf }}\right)$ considered the evaluation of walking trails, sporting facilities (skate lane, sports court, football pitch, etc.), playground, and fitness facilities. Finally, the support services $\left(S_{\text {inf }}\right)$ included data on security staff, medical aid, bus stops, Wi-Fi access, and food services (cafeteria, eatery, snack bar, etc.). Rank values were then defined in order to assign a score for each of the indicators (Table 1).

It can be seen from Table 1, that the rank values recommended by the experts are not fixed numbers, but vary from 0 to a maximum value that depends on the condition assessed. For instance, considering the provision and state of repair of the public toilets, the rank value could be scored as 0 if no toilets are available, as 25 when fully satisfactory, or with an intermediate value between 0 and 25 in partially satisfactory cases. Hence, this range in the rank values permits a more flexible caseby-case evaluation. On the other hand, this approach makes the analysis more subjective, hence requiring a fuzzy modeling. Furthermore, the maximum score of each parameter was decided considering its relative importance. For example, the security staff aspect has a maximum score of 30, while Wi-Fi access, considered less important, has a maximum score of 15 .

Fuzzification of the selected variables was performed using triangular and trapezoidal membership functions, given by:

$\varphi_{F}(x)=\max \left(\min \left(\frac{x-a}{b-a}, 1, \frac{c-x}{c-b^{\prime}}\right), 0\right)$

where $\varphi_{F}(x)$ measures the membership of $x$ in the linguistic value modeled by fuzzy set $F ; a, b, b^{\prime}$, and $c$ are scalar parameters defined by the experts for delimiting the regions of certainty and uncertainty, so that for triangular-shaped functions, the parameter $b$ is equal to $b^{\prime}$ (Fig. 3).

As an example, Fig. 2(c) shows the linguistic values 'low', 'medium', and 'high' and their scalar parameters, enabling computation of the species richness of fauna $\left(S_{\mathrm{fau}}\right)$ using words, taking into account the uncertainty involved in the evaluation of this variable.

The present methodology employed the Mamdani inference system (Mamdani and Assilian, 1975), which is a rule-based model based on conditional statements involving the fuzzy input and output variables, such as: 


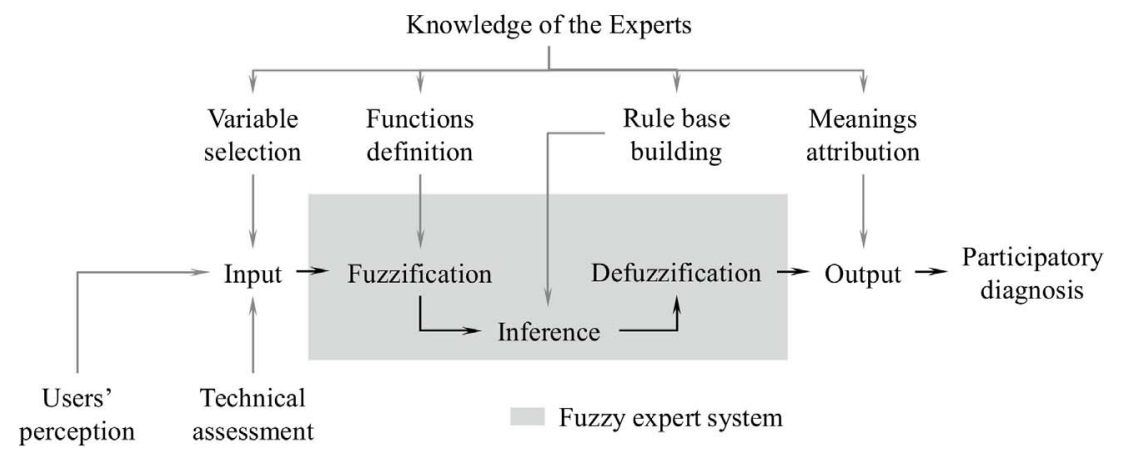

Fig. 1. Proposed approach and the role of the experts in the fuzzy-based modeling of the support system for participatory diagnosis in the management of urban linear parks.

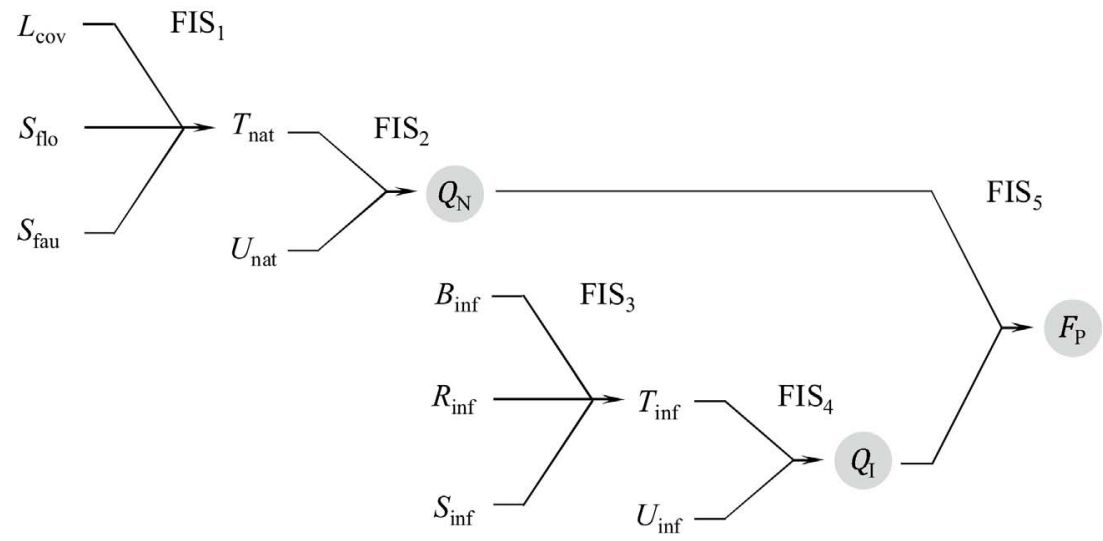

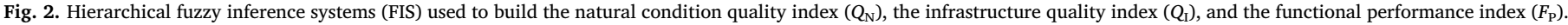

Table 1

Rank values and cumulative scores to guide the technical assessment of park infrastructure by experts.

\begin{tabular}{llll}
\hline \multirow{2}{*}{ Infrastructure } & & Scoring & \\
\cline { 3 - 4 } & & Rank values & Cumulative \\
\hline \multirow{2}{*}{ Basic } & Public toilets & $0-25$ & 25 \\
& Essential facilities & $0-20$ & 45 \\
& Parking lot & $0-20$ & 65 \\
& Night lighting & $0-20$ & 85 \\
& Drinking fountain & $0-15$ & 100 \\
Recreational & Walking track & $0-35$ & 35 \\
& Sporting facilities & $0-25$ & 60 \\
& Playground & $0-25$ & 85 \\
& Fitness facilities & $0-15$ & 100 \\
Support & Security staff & $0-30$ & 30 \\
& Medical aid & $0-30$ & 60 \\
& Bus stops & $0-20$ & 80 \\
& Wi-Fi access & $0-10$ & 90 \\
& Food services & $0-10$ & 100 \\
\hline
\end{tabular}

IF $x$ is $A$ THEN $y$ is $B$

where $x$ is an input in the antecedent part (premise) of the rule, $y$ is an output in its consequent part (conclusion); $A$ and $B$ are linguistic values defined by fuzzy sets in the $x$ and $y$ ranges, respectively.

The proposed rule base is shown in Tables $2-5$. The integration of the technical assessment by experts with the users' perception about the park infrastructure followed the same rule base presented in Table 3 for the natural condition assessment.

As an example, the following if-then rule (conditional statement) can be seen from Table 2: IF $S_{\text {fau }}$ is medium AND $S_{\text {flo }}$ is high AND $L_{\text {cov }}$ is acceptable THEN $T_{\text {nat }}$ is good $(G)$. It is this rule-based modeling that provides a user-friendly structure (Adriaenssens et al., 2004), due to its ease of interpretation, hence making the fuzzy approach more attractive, compared to other computer-aided techniques.

The Mamdani inference system used the t-norm $\wedge$ (minimum) to assess the antecedents of each rule, and the s-norm $\vee$ (maximum) to aggregate its consequents. Hence, the Mamdani-type fuzzy model operated by means of a max-min relational composition, $R$ :

$R(x, y)=\max _{1 \leq i \leq r}\left(\varphi_{A_{i}}(x) \wedge \varphi_{B_{i}}(y)\right)$

where $r$ is the total number of rules.

Defuzzification was performed using the centroid method to pro-
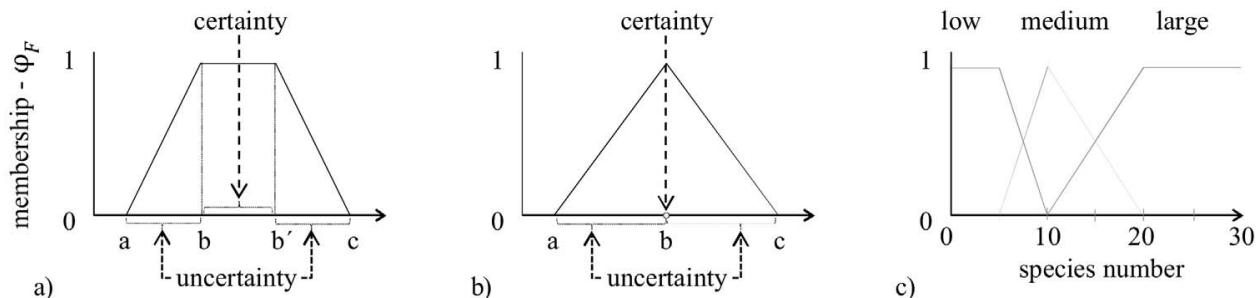

c)

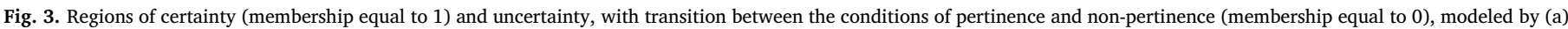
trapezoidal and (b) triangular-shaped functions; (c) input variable example based on linguistic values for the species richness of fauna $\left(S_{\text {fau }}\right)$. 
Table 2

Rule base in tabular form for the technical assessment of the natural condition by experts $\left(T_{\text {nat }}\right)$ as: very bad $(V B)$, bad $(B)$, regular $(R)$, good $(G)$, and very good $(V G)$.

\begin{tabular}{|c|c|c|c|c|c|}
\hline \multicolumn{2}{|c|}{ Species richness } & \multicolumn{4}{|c|}{ Land cover $-L_{\mathrm{cov}}$} \\
\hline Fauna $-S_{\text {fau }}$ & Flora $-S_{\text {flo }}$ & Inadequate & Low & Acceptable & Ideal \\
\hline \multirow[t]{3}{*}{ Low } & Low & $V B$ & $V B$ & $B$ & $R$ \\
\hline & Medium & $V B$ & $B$ & $R$ & $R$ \\
\hline & High & $B$ & $B$ & $R$ & $R$ \\
\hline \multirow[t]{3}{*}{ Medium } & Low & $V B$ & $B$ & $R$ & $R$ \\
\hline & Medium & $B$ & $R$ & $G$ & $V G$ \\
\hline & High & $B$ & $R$ & $G$ & $V G$ \\
\hline \multirow[t]{3}{*}{ High } & Low & $B$ & $B$ & $R$ & $R$ \\
\hline & Medium & $R$ & $R$ & $V G$ & $V G$ \\
\hline & High & $R$ & $R$ & $V G$ & $V G$ \\
\hline
\end{tabular}

Table 3

Rule base in tabular form for the natural condition quality index $\left(Q_{N}\right)$ as: very bad $(V B)$, bad $(B)$, regular $(R)$, good $(G)$, and very good $(V G)$.

\begin{tabular}{llllllll}
\hline & \multicolumn{7}{c}{ Technical assessment by experts } \\
\cline { 3 - 7 } & & Very bad & Bad & Regular & Good & Very good \\
\hline \multirow{2}{*}{ Users' perception } & Bad & $V B$ & $V B$ & $R$ & $R$ & $G$ \\
& Regular & $B$ & $B$ & $R$ & $G$ & $G$ \\
& Good & $B$ & $R$ & $R$ & $G$ & $V G$ \\
\hline
\end{tabular}

Table 4

Rule base in tabular form for the technical assessment of the infrastructure by experts $\left(T_{\text {inf }}\right)$ as: very bad $(V B)$, bad $(B)$, regular $(R)$, good $(G)$, and very good $(V G)$.

\begin{tabular}{|c|c|c|c|c|}
\hline \multicolumn{2}{|c|}{ Infrastructure } & \multicolumn{3}{|c|}{ Support services } \\
\hline Basic & Recreational & Bad & Regular & Good \\
\hline \multirow[t]{3}{*}{ Bad } & Bad & $V B$ & $B$ & $B$ \\
\hline & Regular & $B$ & $B$ & $R$ \\
\hline & Good & $B$ & $R$ & $G$ \\
\hline \multirow[t]{3}{*}{ Regular } & Bad & $B$ & $B$ & $R$ \\
\hline & Regular & $B$ & $R$ & $G$ \\
\hline & Good & $R$ & $G$ & $G$ \\
\hline \multirow[t]{3}{*}{ Good } & Bad & $B$ & $R$ & $G$ \\
\hline & Regular & $R$ & $G$ & $G$ \\
\hline & Good & $G$ & $G$ & $V G$ \\
\hline
\end{tabular}

Table 5

Rule base in tabular form for the park functional performance $\left(F_{\mathrm{P}}\right)$ as: very low $(V L)$, low $(L)$, medium $(M)$, high $(H)$, and very high $(V H)$.

\begin{tabular}{rlllllll}
\hline & \multicolumn{5}{c}{ Infrastructure quality index } \\
\cline { 3 - 8 } & & Very bad & Bad & Regular & Good & $\begin{array}{l}\text { Very } \\
\text { good }\end{array}$ \\
\cline { 3 - 8 } & & & & & & & \\
\hline Natural condition & Very bad & $V L$ & $V L$ & $L$ & $L$ & $L$ \\
quality index & Bad & $V L$ & $L$ & $L$ & $M$ & $M$ \\
& Regular & $L$ & $L$ & $M$ & $M$ & $M$ \\
& Good & $L$ & $M$ & $M$ & $H$ & $H$ \\
& Very good & $L$ & $M$ & $M$ & $H$ & $V H$ \\
\hline
\end{tabular}

duce a discrete output, in order to guide the interpretation and use of the model result. Since the centroid method returns the center of the area under the curve, the defuzzified values were standardized using:

$Y^{\prime}=Y_{e s t}\left(Y-Y_{\min }\right) /\left(Y_{\max }-Y_{\min }\right)$

where $Y_{\text {est }}$ is the highest value in the output variable range, $Y$ is the defuzzified value, and $Y_{\min }$ and $Y_{\max }$ are the lowest and highest values, respectively, generated in the defuzzification process.
Thus, two inference systems were firstly obtained. The first system $\left(\mathrm{FIS}_{1}\right)$ modeled the technical assessment of the natural condition by experts $\left(T_{\text {nat }}\right)$, while the second system $\left(\mathrm{FIS}_{2}\right)$ integrated the FIS ${ }_{1}$ output with the users' perception ( $U_{\text {nat }}$ ), providing as a result the natural condition quality index $\left(Q_{N}\right)$, shown in Fig. 4.

Species richness is an important factor in the composition of ecological corridors, while adequate coverage of land by vegetation is important in the hydrological cycle, since it can prevent erosion and protect watercourses (Frischenbruder and Pellegrino, 2004; Cook, 2002; Bryant, 2006). Therefore, by considering the species richness of fauna and flora, together with land cover, the integrated analysis in FIS 1 included useful indicators of the ecological performance of linear parks.

Fig. 4 shows the integration by the second system (FIS ${ }_{2}$ ) of the outcomes from the technical assessment by experts $\left(T_{\text {nat }}\right)$ given by FIS ${ }_{1}$ with those based on the users' perception $\left(U_{\text {nat }}\right)$, resulting in the natural condition quality index $\left(Q_{N}\right)$. In this way, by enabling a participatory diagnosis, the fuzzy approach can achieve results that outperform classical top-down processes, as pointed out elsewhere (Etienne et al., 2011; Reed, 2008; Fraser et al., 2006).

As mentioned above, three more support systems were obtained. The third system $\left(\mathrm{FIS}_{3}\right)$ modeled the technical assessment of infrastructure by experts $\left(T_{\text {inf }}\right.$ ), while the fourth system $\left(\mathrm{FIS}_{4}\right)$ integrated the $\mathrm{FIS}_{3}$ output with the users' perception $\left(U_{i n f}\right)$, resulting in the infrastructure quality index $\left(Q_{\mathrm{I}}\right)$. The final system $\left(\mathrm{FIS}_{5}\right)$ integrated the $\mathrm{FIS}_{2}$ and $\mathrm{FIS}_{4}$ outputs, resulting in the functional performance index $\left(F_{\mathrm{P}}\right)$, as shown in Fig. 5.

A number of tools have been employed previously to support participatory environmental management. Some methodologies, such as Bayesian belief networks, Who Counts Matrices, spider diagrams, and Venn diagrams, involve identifying and evaluating key variables and the stakeholders' relationships and roles (Lynam et al., 2007). Metagame theory consists of analyzing likely scenarios and stakeholders who might exert an influence on the issues involved (Jeffers, 1997). The Scenarios method helps to predict the desired future and identify the essential steps required to achieve promising results (Peterson et al., 2003). The pebble distribution method aims to clarify the priorities of the target group (Sheil and Liswanti, 2007). Hierarchical analysis techniques compare the outcomes of different planning alternatives (Hujala and Kurttila, 2010). Multi-criteria analysis methods can assist in the evaluation of multiple variables influencing the decision-making process (Myllyviita et al., 2011). Communitarian biomaps (Bressane et al., 2011) can be used for spatial mapping of environmental issues, based on the participants' knowledge.

The contribution of the methodological approach proposed in the present paper is the use of fuzzy modeling to integrate technical knowledge (evaluation by experts) with the understanding of the community (users' perception), in order to support participatory diagnosis of the functional performance of linear parks, taking into account the uncertainties due to the inherent subjectivity and vagueness of the assessment process.

\section{Case study}

The Tiquatira linear park has an area of $320,000 \mathrm{~m}^{2}$ and is located in the eastern zone of São Paulo city, São Paulo State, Brazil (Fig. 6).

The Tiquatira is the first linear park of São Paulo city, created along the banks of the river with the same name. As an environmental protection area that allows sustainable use, this park receives many people daily, representing an important green space for outdoor social activities.

Despite being inside the urban area, the Tiquatira park lies at the edge of the buffer zone of the São Paulo City Green Belt Biosphere Reserve, recognized by UNESCO in the early 1990s for protecting Atlantic Forest remnants and promoting the development of sustainable uses and social practices. Nevertheless, one of the most challenging tasks is to harmonize the social and ecological functions, since the 

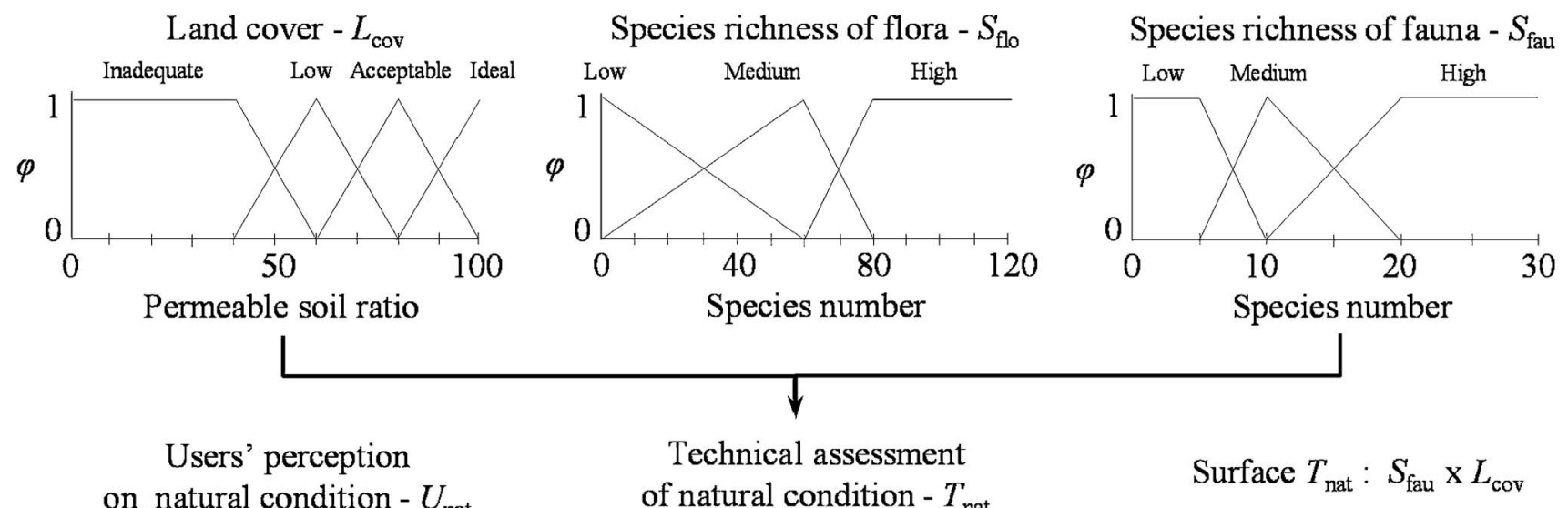

Users' perception on natural condition - $U_{\text {nat }}$

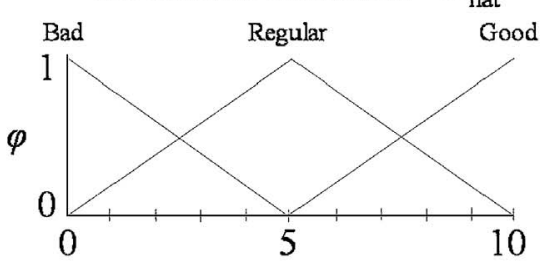

Score assigned based on interview

\section{Technical assessment of natural condition $-T_{\text {nat }}$}

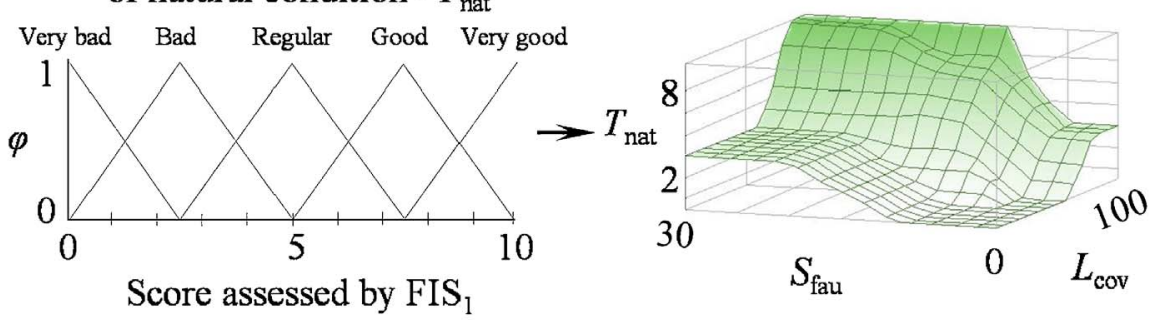

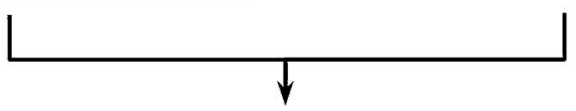

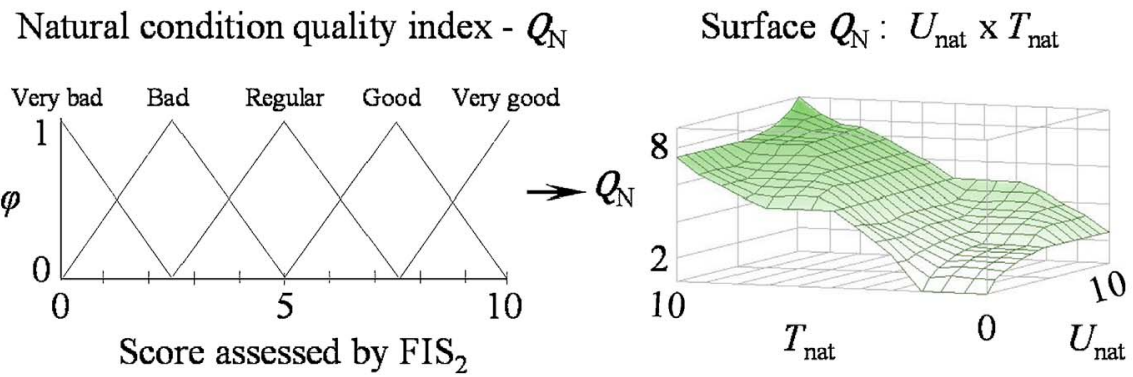

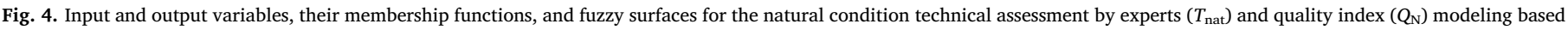
on the species richness of fauna $\left(S_{\text {fau }}\right)$ and flora $\left(S_{\text {flo }}\right)$, land cover $\left(L_{\text {cov }}\right)$, and users' perception $\left(U_{\text {nat }}\right)$.

urban landscape of the São Paulo City Green Belt is highly complex, with growth of the built-up area being concentrated at the fringes of the buffer zone (Douglas et al., 2011), where the Tiquatira park is located.

The São Paulo City Green Belt is home to over 250 endangered species and about $10 \%$ of the Brazilian population, and the region produces the equivalent of $20 \%$ of the country's gross domestic product. Zoning of the urban green spaces as buffer zones has been employed as a land use management strategy, with the aim of connecting the core zones and minimizing negative environmental impacts, while at the same time improving human quality of life. For these reasons, the Tiquatira park was selected for use in the present case study.

The main materials used in this evaluation were data concerning the infrastructure and natural condition of the Tiquatira linear park. Data were acquired from official sources of the municipal government and the São Paulo State environmental agency. In addition, remote sensing and field surveys were undertaken in the park for both the technical evaluation and for the collection of data concerning the users' perception of the park.

The technical assessment consisted of the observation of indicator variables in loco by an expert. The biological species richness was measured from observation of the fauna and flora species present and the perceptions of passers-by in the park area, and the land cover was evaluated by remote sensing, using photointerpretation to measure the area with permeable soil. Technical assessment of the park infrastruc- ture was performed by analysis of the parameters of each of its indicators, using the rank values shown in Table 1.

In order to achieve participatory diagnosis of the quality of the natural condition and the infrastructure of the linear park, the users' perception was obtained by means of interviews using multiple-choice questions. During these interviews, 103 respondents (park users) were asked to give scores from 0 (for bad quality) up to 10 (for a good condition). In addition, one open-ended question was asked in order to obtain further understanding of the users' perception of negative and positive aspects related to the natural condition and the infrastructure of the park.

In the case of land cover $\left(L_{c o v}\right)$, it was estimated that permeable soil in the Tiquatira park correspond to $90.4 \%$ of the total area. This is a substantial proportion that would ensure downward movement of water into the soil and recharge of the groundwater, besides minimizing runoff, loss of topsoil by erosion, and the silting up of river channels and other water bodies (Ilstedt et al., 2007).

Constructions including a parking lot, public toilets, an outdoor amphitheater, and multi-sports courts were the main land uses occupying the impermeable surface of the park $(9.6 \%$ of the total area). Nevertheless, in the western sector of the park, there are unauthorized occupation by precarious housing (shantytown), which reduced the area of permeable soil and but also represented a source of pollution for the watercourse, with potential risk to the inhabitants. Unfortunately, 

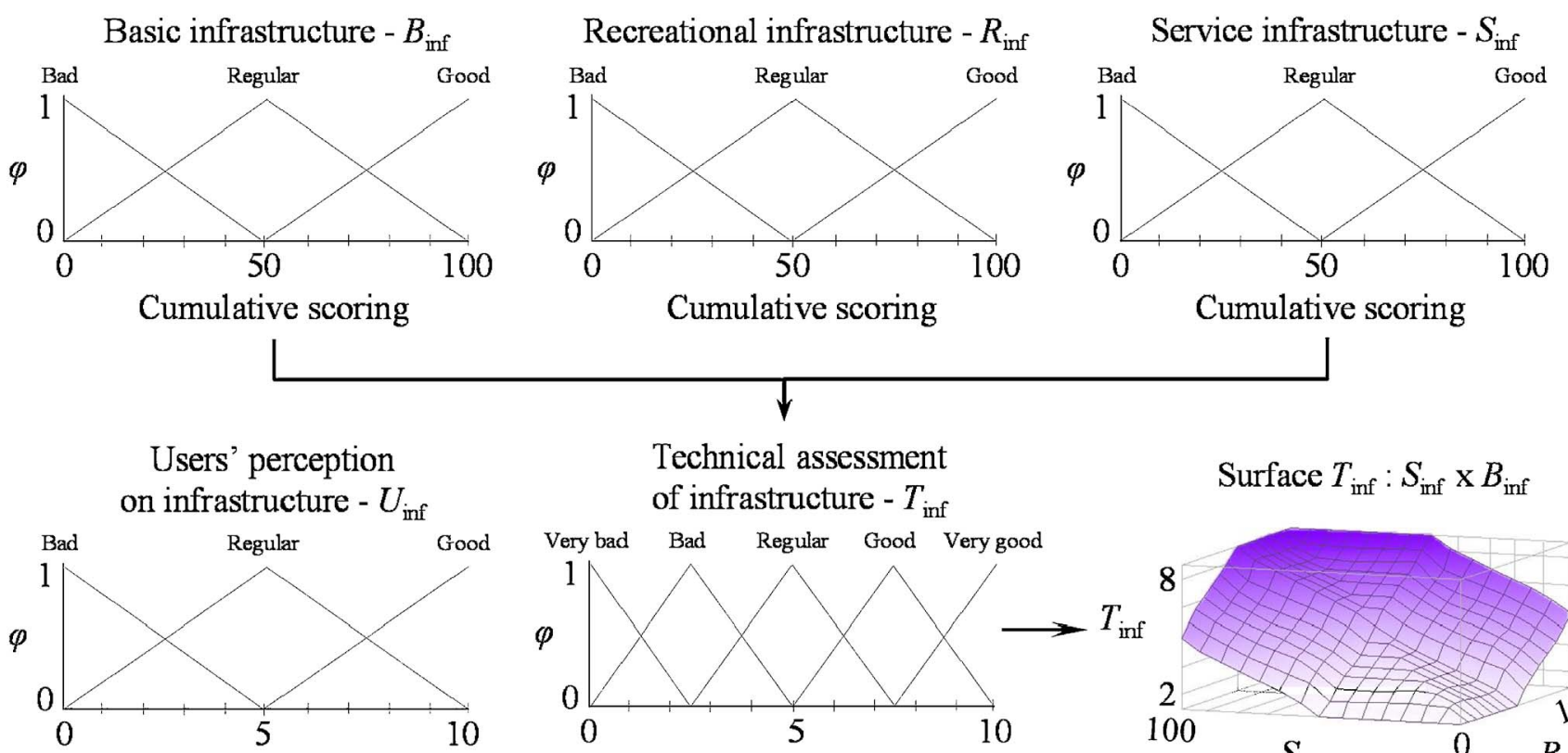

Score assigned based on interview
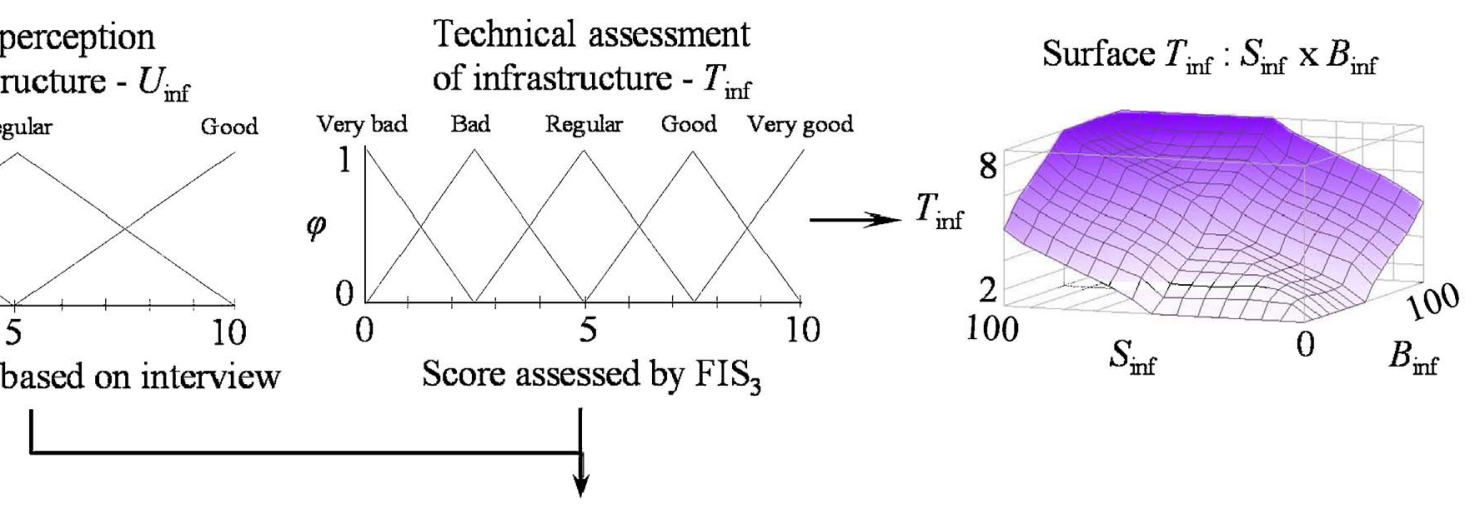

Natural condition quality index $-Q_{\mathrm{N}} \quad$ Infrastructure quality index $-Q_{\mathrm{I}}$

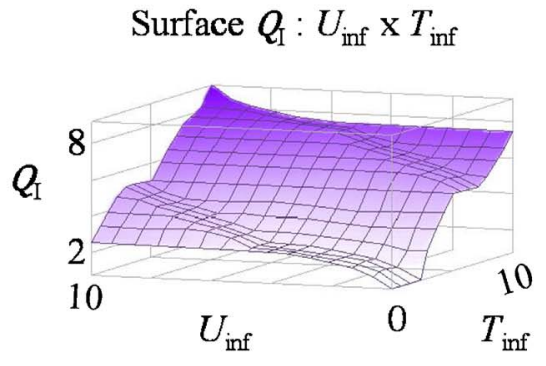

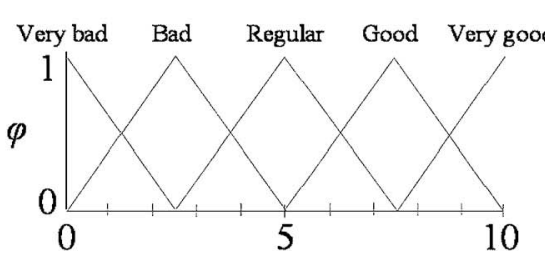

Score assessed by FIS 2

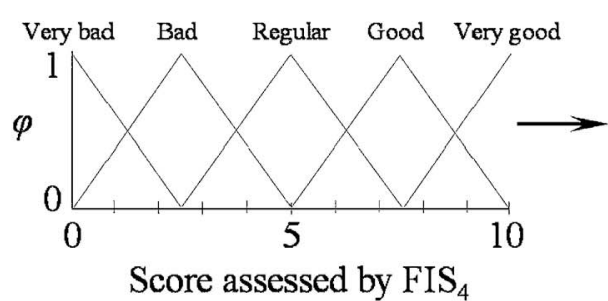

Score assessed by $\mathrm{FIS}_{4}$

\section{$\downarrow$}

Functional performance index $-F_{\mathrm{P}}$

Surface $F_{\mathrm{P}}: Q_{\mathrm{N}} \times Q_{\mathrm{I}}$
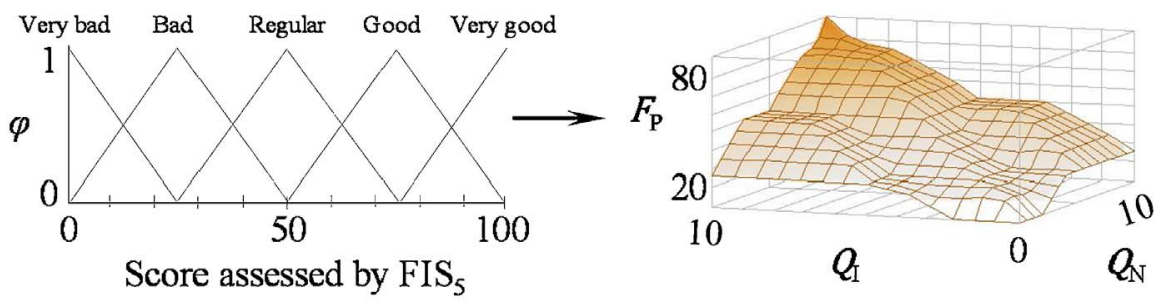

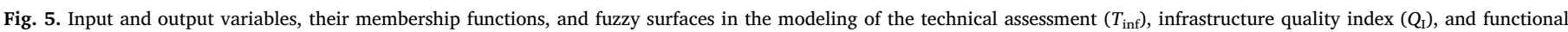
performance index $\left(F_{\mathrm{P}}\right)$.

this is a common issue in the green areas of peri-urban neighborhoods, making the recovery and conservation of such areas highly dependent on the engagement of the community in the management of the natural resources (Evans et al., 2006).

During the field surveys, 102 species of flora were identified, including the following Brazilian native tree species: Caesalpinia echinata, Caesalpinia peltophoroides, Cecropia hololeuca, Cedrela fissilis, Ceiba speciosa, Centrolobium tomentosum, Croton floribundus, Lafoensia glyptocarpa, Schinus terebinthifolius, and Syagrus romanzoffiana. Among these trees, the Caesalpinia echinata identified during the field surveys is one of endangered species present in the São Paulo City Green Belt
Biosphere Reserve, which reinforces the importance of parks like the Tiquatira for the protection of biodiversity, as indicated by Bruner et al. (2001).

Fifteen fauna species were observed in the park area: Brotogeris tirica, Caracara plancus, Coereba flaveola, Crotophaga ani, Estrilda astrild, Eupetomena macroura, Furnarius rufus, Machetornis rixosa, Mimus saturninus, Pitangus sulphuratus, Pseudoleistes guirahuro, Tangara sayaca, Todirostrum cinereum, Troglodytes musculus, and Turdus rufiventris.

In spite of this species richness, according to the users' perception, the natural condition of the park was assessed as 6.69 , corresponding to the average value of the scores assigned by the 103 respondents. During 


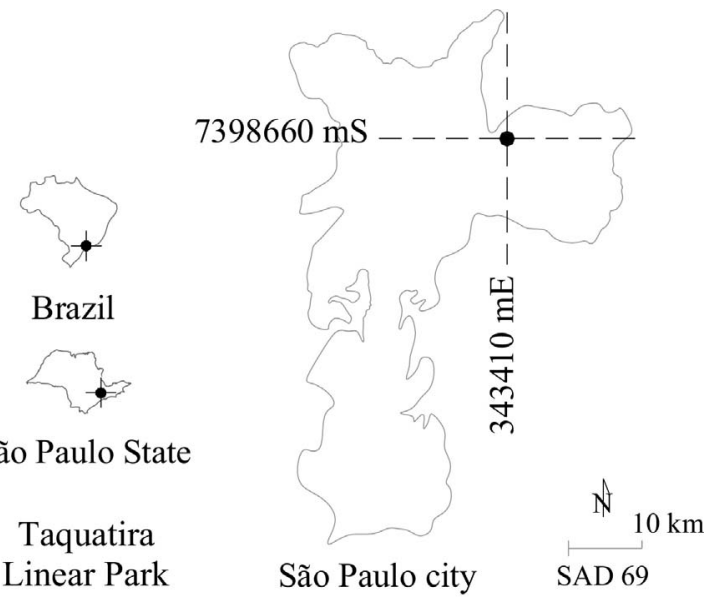

Fig. 6. Location of the Tiquatira linear park in the urban area of São Paulo city, São Paulo State, Brazil.

the interviews, most of the respondents found no negative aspects associated with the natural condition, but almost $20 \%$ noted the poor condition of the vegetation. Almost all the respondents considered the low noise level inside the park to be a positive aspect. As reported by Laurie (1975), perception depends on a number of factors, especially learned values and the corresponding preferences in terms of the aspects considered important by the individual. Özgüner and Kendle (2006) reported that the maintenance of natural features is among the urban landscape features that have greatest influence on the perception and preferences of the public. Hence, aspects that were more apparent to the users, such as the vegetation eliminated due to illegal occupation, or areas with bare soil, seemed to have a strong effect on their perception concerning the natural condition of the park.

The data for the numbers of observed species (102 and 15 species of flora and fauna, respectively) and the proportion of permeable soil $(90.4 \%)$ were used in the first fuzzy inference system $\left(\right.$ FIS $\left._{1}\right)$ to integrate the indicators of land cover and species richness, resulting in a score of 8.37, corresponding to the technical assessment. In the second system $\left(\mathrm{FIS}_{2}\right)$, this result was then integrated with the score based on users' perception, providing the natural condition quality index of the Taquatira park (8.16), as shown in Fig. 7.

The Taquatira park achieved the maximum score (100 points) in the technical assessment of the basic infrastructure, since in the opinion of the experts, all the indicator items (public toilets, essential facilities, parking lot, etc.) were in good condition. Although the recreational infrastructure was complete, some of the scores given by the experts were lower, due to a lack of maintenance of some sporting facilities observed during the field surveys. This reduced the score to 95, which could still be considered very high. However, the support services received a poor assessment, with a score of 60 . The experts found that within the area of the park, there were bus stops, Wi-Fi access, and security staff, but there were no food services or medical assistance.

In terms of the users' perception, the park infrastructure achieved an average score of 8.1 . When asked about the negative issues, $30 \%$ of those interviewed identified a lack of maintenance and $32 \%$ considered insecurity as the main factor. On the other hand, almost all the respondents stated that good access to the park was provided by public transport, and $76 \%$ found that the recreational infrastructure was satisfactory.

Hence, according to the technical assessment indicators (basic infrastructure, recreational infrastructure, and support services), the third fuzzy inference system $\left(\mathrm{FIS}_{3}\right)$ scored the Tiquatira park infrastructure at 8.04, which when integrated (by FIS 4 ) with the score of 8.1 based on the users' perception, provided an infrastructure quality index score of 8.07, as shown in Fig. 8.

It can be seen from Figs. 7 and 8 that the values of all the indicators had membership of at least two classes or fuzzy sets, considering the uncertainties in classification of the conditions evaluated. For instance, the technical assessment $\left(T_{\text {nat }}\right)$, scored by FIS $_{1}$, defined the natural condition of the park as a transition between the classes good and very good (see Fig. 7), so that both were considered during the inference process.

Using $\mathrm{FIS}_{2}$ and $\mathrm{FIS}_{4}$, the fuzzy-based approach enabled integration of the evaluation by experts with the users' perception, hence providing a participatory diagnosis that included consideration of uncertainties. For the proposed systems using a max-min composition, in each rule the minimum operator was assigned to the consequent with the smallest membership among those of the input fuzzy sets. As an example from Fig. 8, the smallest users' perception membership ( $\varphi_{U_{\text {inf }}}$ smaller than $\varphi_{T_{\text {inf }}}$ ) was assigned to the first rule consequent. This first consequent was aggregated with the second rule consequent by the union of fuzzy sets using the maximum operator. Next, the gravity center of the resulting area was measured by the centroid method, obtaining a score of 7.58. Then, by standardizing after defuzzification, the infrastructure quality index of the Tiquatira park was scored at 8.07. The inference process for functional performance $\left(F_{\mathrm{P}}\right)$ was computed similarly, as presented in Fig. 9.

As the qualities of the infrastructure and the natural condition were scored between good and very good, in both cases with indexes above 8.0 , the functional performance $\left(F_{\mathrm{P}}\right)$ obtained by the participatory

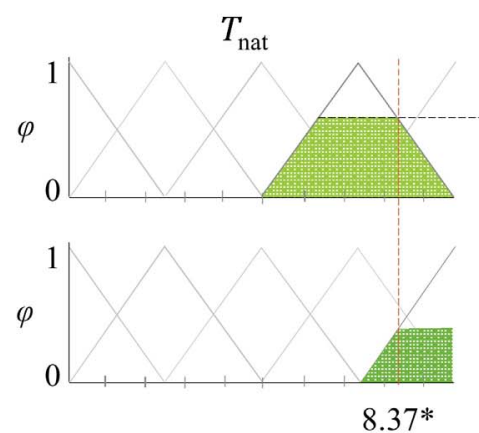

Score assessed by FIS

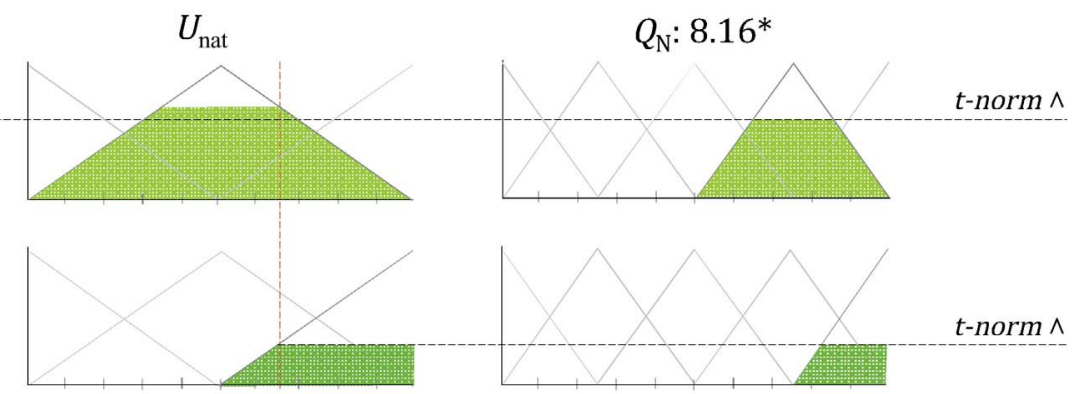

6.69

Score based on interviews

* Standardized values after defuzzification

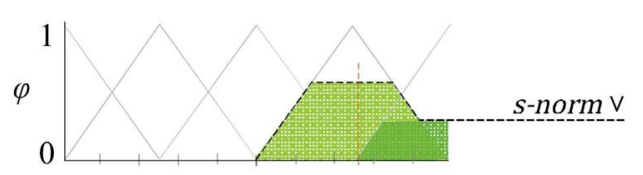

7.65

Score assessed by FIS $_{2}$

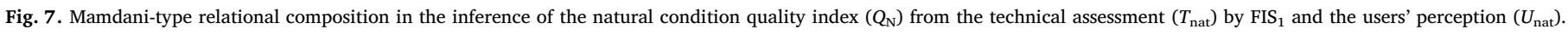




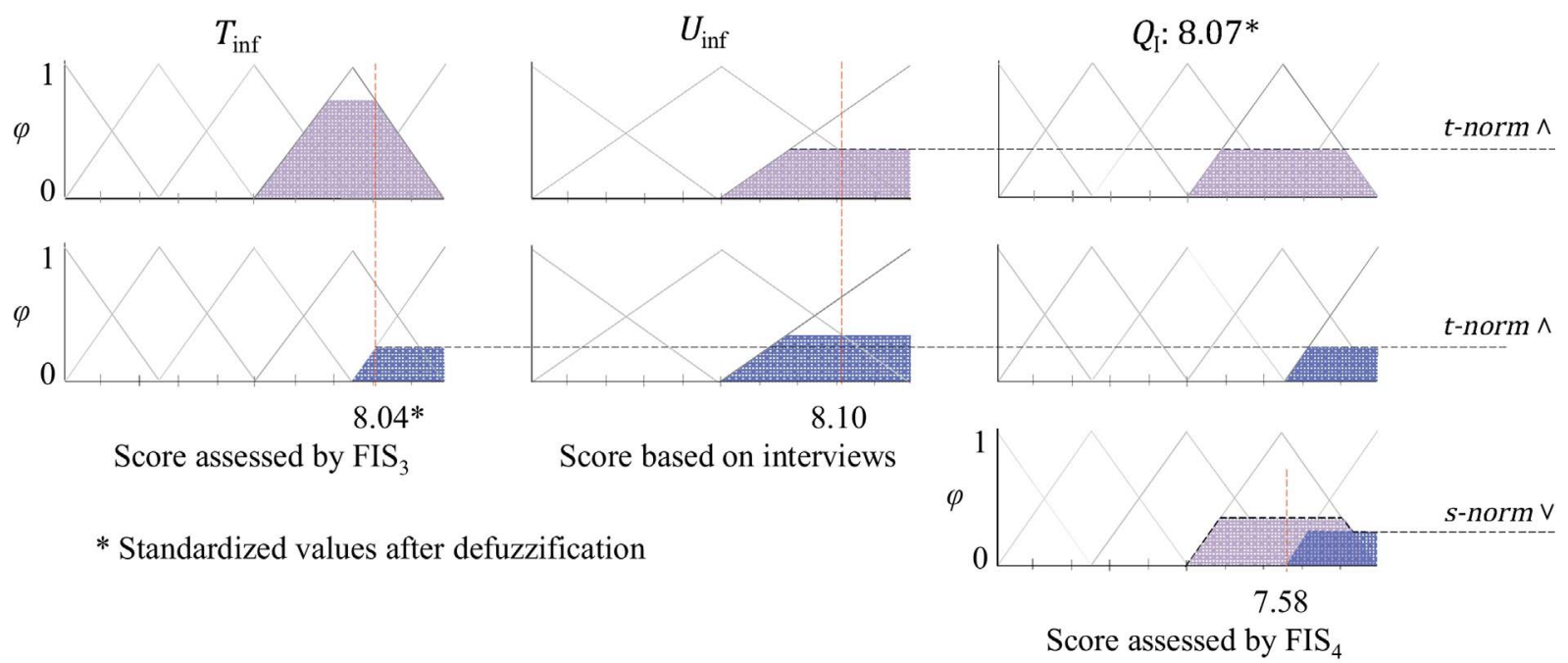

Fig. 8. Mamdani-type relational composition in the inference of the infrastructure quality index $\left(Q_{\mathrm{I}}\right)$ from the technical assessment $\left(T_{\text {inf }}\right)$ by FIS $S_{3}$ and the users' perception $\left(U_{\text {inf }}\right)$.

diagnosis was also highly rated, with a score of 80.6. This park management score indicated that there was high functional performance, both for ecological purposes and social services. However, in order to achieve a higher score ( $F_{\mathrm{p}}$ above 87.5 , indicative of very high performance), measures such as vegetation recovery in areas with bare soil and unauthorized occupation would be essential to improve the natural condition of the park, together with ongoing infrastructure maintenance. The provision of food services and medical aid could then make the Taquatira park a reference model of effective management. On the other hand, although there may be limited resources for improvement of all the parks in an administrative area, the $F_{\mathrm{p}}$ can be used for a hierarchical analysis, classifying the parks in terms of priority, in order to guide the management investments and measures.

It can be seen from this case study that fuzzy modeling allows the incorporation of community knowledge, providing participatory diagnosis in the management of linear parks. This participatory management approach can help to minimize conflict and maximize equitable benefit-sharing, as discussed by Ostrom et al. (1999).

By participating in the diagnosis of a park, its users become aware of existing problems and the need for eco-friendly behavior in order to protect the natural condition and ensure satisfactory use of the infrastructure. Moreover, community engagement enables the identification of priorities based on the satisfaction and interests of users, supporting a park management policy that meets the expectations and needs of the public (Colfer, 2005).

It should be noted that the points of view of park users are strongly influenced by individual preferences, which are the result of the combined effects of cultural inheritance, personal tastes, psychology, learned culture, socioeconomic determinants, and biological origin, which makes the perception phenomenon highly subjective. Thus, the fuzzy approach offers one way to deal with this subjectivity, among other causes of uncertainty.

\section{Conclusions}

A fuzzy-based modeling procedure is proposed for supporting participatory diagnosis in the management of urban linear parks. In consultation with experts, fuzzy inference systems were constructed using ecological and social functional indicators, and indexes were modeled for an integrated evaluation of the natural condition, infrastructure, and functional performance of linear parks.

In a case study, application of the fuzzy system indicated that the Taquatira park presented high functional performance, but that some improvements were desirable or even required, such as the recovery of vegetation cover in disturbed areas, additional support services, and infrastructure maintenance. The case study also enabled understanding

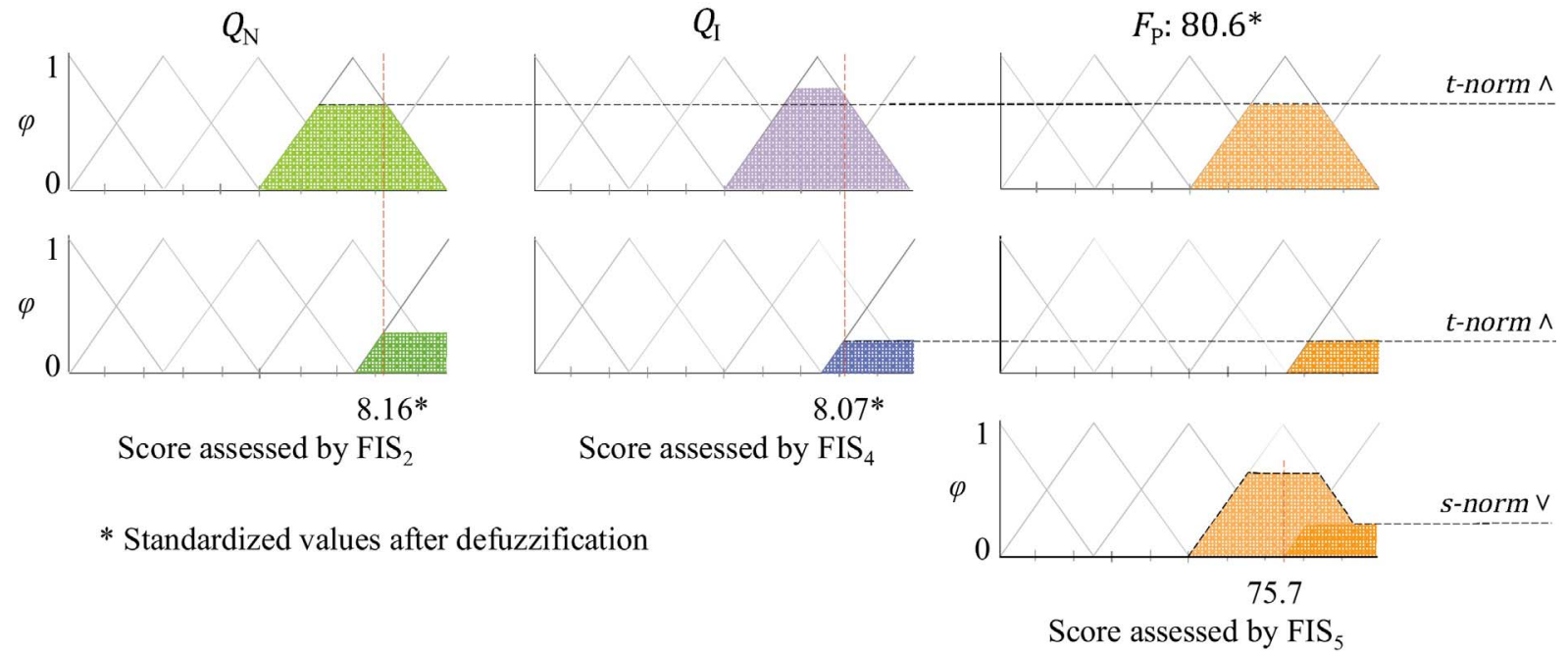

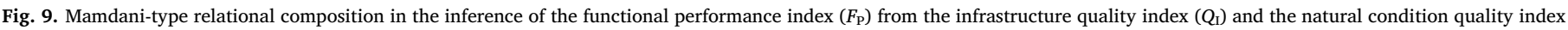
$\left(Q_{N}\right)$. 
of the functioning of the fuzzy system and its potential uses.

While participatory diagnosis is clearly important, there are challenges associated with its use. Inaccuracies could arise because the numbers of fauna and flora species were estimated from observations, while the land cover was evaluated by photointerpretation. The range of values used for assessing the infrastructure allowed for greater caseby-case flexibility, but also increased subjectivity. Furthermore, in both indicator variable sets (infrastructure and natural condition), the scores assigned by experts and users has subjective aspects. Such issues of uncertainty increase the suitability of the fuzzy approach, since it provides the possibility of partial transition between pertinence and non-pertinence conditions.

The procedure introduced here can be considered a promising computer-aided tool, which can assist in participatory decision-making in the management of linear parks. Nevertheless, there are still issues that require improvement, such as the weighting of variables according to the indicators' significance, on a case-by-case basis. Future works could consider the use of techniques able to provide weightings of the indicators according to their relative importance. Additionally, new indicator variables could be included to strengthen the fuzzy system proposed in the present study.

\section{Acknowledgement}

This work was supported by the Coordination for the Improvement of Higher Education Personnel, a Foundation within the Ministry of Education in Brazil.

\section{References}

Özgüner, H., Kendle, A.D., 2006. Public attitudes towards naturalistic versus designed landscapes in the city of Sheffield (UK). Landsc. Urban Plann. 74 (2), 139-157.

Adriaenssens, V., Baets, B., Goethals, P.L.M., Pauw, N., 2004. Fuzzy rule-based models for decision support in ecosystem management. Sci. Total Environ. 319, 1-12.

Alberti, M., 2010. Maintaining ecological integrity and sustaining ecosystem function in urban areas. Curr. Opin. Environ. Sustain. 2 (3), 178-184.

Ascough, J.C., Maier, H.R., Ravalico, J.K., Strudley, M.W., 2008. Future research challenges for incorporation of uncertainty in environmental and ecological decisionmaking. Ecol. Modell. 219, 383-399.

Bressane, A., Mochizuki, P.S., Caram, R.M., Roveda, J.A.F., 2016. A system for evaluating the impact of noise pollution on the population's health. Rep. Public Health 32 (5), $1-11$.

Bressane, A., Salvador, N.N.B., Silva, P.O., 2011. The use of communitarian structured biomaps for participative environmental planning. In: Proceedings of the 12th International Specialized Conference on Watershed and River Basin Management. International Water Association, Brazil, Recife, 2011 September 14-16, 2011. (Proceedings on CD-ROM)

Bruner, A.G., Gullison, R.E., Rice, R.E., Fonseca, G.A.B., 2001. Effectiveness of parks in protecting tropical biodiversity. Science 291 (5501), 125-128.

Bryant, M.M., 2006. Urban landscape conservation and the role of ecological greenways at local and metropolitan scales. Landsc. Urban Plan 76, 23-44.

Canavese, D., Ortega, N.R.S., Giatti, L.L., 2012. Ecosystem approach and the fuzzy logic: a dialectical proposal for information on Environmental Health. Eng. Sanit. Ambient. 17 (4), 363-369.

Colfer, C.J.P., Prabhu, R., McDougall, C., Porro, N.M., Porro, R., 1999. Who counts most? Assessing human well-being in sustainable forest management. The Criteria \& Indicators Toolbox Series 8 Bogor, Center for International Forestry Research.

Colfer, C.J.P., 2005. The Complex Forest: Communities, Uncertainty and Adaptive Collaborative Management. Center for International Forestry Research, Washington. Conine, A., Xiang, W.-N., Young, J., Whitley, D., 2004. Planning for multi-purpose greenways in Concord: North Carolina. Landsc. Urban Plan 68, 271-287.

Cook, E.A., 2002. Landscape structure indices for assessing urban ecological networks. Landsca. Urban Plan. 58, 269-280.

Cornelis, A., Hermy, M., 2004. Biodiversity relationships in urban and suburban parks in Flanders. Landsc. Urban Plan. 69, 385-401.

Douglas, I., Goode, D., Houck, M., Wang, R., 2011. The Rutledge Handbook of Urban Ecology. Taylor \& Francis Group, New York.

Etienne, M., Toit, D.R.D., Pollard, S., 2011. ARDI: a co-construction method for participatory modeling in natural resources management. Ecol. Soc. 16 (1), 44.

Evans, K., Velarde, S.J., Prieto, R.P., Rao, S.N., Sertzen, S., Dávila, K., Cronkleton, P. Jong, W., 2006. Field Guide to the Future: Four Ways for Communities to Think Ahead. Center for International Forestry Research, Nairobi.

Fraser, E.D.G., Dougill, A.J., Mabee, M.R., Reed, M., McAlpine, P., 2006. Bottom up and top down: analysis of participatory processes for sustainability indicator identification as a pathway to community empowerment and sustainable environmental management. J. Environ. Manage. 78, 114-127.

Frischenbruder, M.T.M., Pellegrino, P., 2004. Using greenways to reclaim nature in Brazilian cities. Landsc. Urban Plan. 76, 67-78.

Giordano, L.C., Riedel, P.S., 2008. Multi-criteria spatial decision analysis for demarcation of greenway: a case study of the city of Rio Claro, São Paulo, Brazil. Landsc. Urban Plan. 84, 301-311.

Godbey, G.C., Caldwell, L.L., Floyd, M., Payne, L.L., 2005. Contributions of leisure studies and recreation and park management research to the active living agenda. Am. J. Prev. Med. 28, 150-158.

Hujala, T., Kurttila, M., 2010. Facilitated group decision making in hierarchical contexts In: In: Kilgour, D.M., Eden, C. (Eds.), Handbook of Group Decision and Negotiation, Advances in Group Decision and Negotiation, fourth volume. Springer, Netherlands, pp. 325-337.

Icaga, Y., 2007. Fuzzy evaluation of water quality classification. Ecol. Indic. 7 (3), $710-718$.

Ilstedt, U., Malmer, A., Verbeeten, E., Murdiyarso, D., 2007. The effect of afforestation on water infiltration in the tropics: a systematic review and meta-analysis. For. Ecol. Manage. 251 (1-2), 45-51.

Jamwal, P., Mittal, A.K., Mouchel, J.M., 2008. Effects of urbanization on the quality of the urban runoff for Delhi watershed. Urban Water J. 5 (3), 247-257.

Janssen, J.A.E.B., Krol, M.S., Schielen, R.M.J., Hoekstra, A.Y., Kok, J.L., 2010. Assessment of uncertainties in expert knowledge, illustrated in fuzzy rule-based models. Ecol. Modell. 221, 1245-1252.

Jeffers, J.N.R., 1997. Conflict analysis and resolution, a computer based approach. In: Solberg, B., Miina, S. (Eds.), Conflict Management and Public Participation in Land Management. European Forest Institute, Joensuu, pp. 99-108.

Jim, C.Y., Chen, S.S., 2002. Comprehensive greenspace planning based on landscape ecology principles in compact Nanjing city, China. Landsc. Urban Plan. 65, 95-116.

Kellert, S.R., Mehta, J.N., Ebbin, S.A., Lichtenfeld, L.L., 2000. Community natural resource management: promise, rhetoric, and reality. Soc. Nat. Resour. 13, 705-715.

Krueger, T., Page, T., Hubacek, K., Smith, L., Hiscock, K., 2012. The role of expert opinion in environmental modelling. Environ. Model. Softw. 36, 4-18.

Laurie, M., 1975. An Introduction to Landscape Architecture. American Elsevier Publishing Company, New York.

Lermontov, A., Yokoyama, L., Lermontov, M., Machado, M.A.S., 2009. River quality analysis using fuzzy water quality index Ribeira do Iguape river watershed. Braz. Ecol. Indic. 9, 1188-1197.

Liu, D., Zhou, Z., 2012. Water quality evaluation based on improved fuzzy matter-element method. J. Environ. Sci. 24 (7), 1210-1216.

Liu, L., Zhou, J., An, X., Zhang, Y., Yang, L., 2010. Using fuzzy theory and information entropy for water quality assessment in Three Gorges region. China Expert Syst. Appl. 37, 2517-2521.

Lynam, T., Jong, W., Sheil, D., Kusumanto, T., Evans, K., 2007. A review of tools for incorporating community knowledge, preferences, and values into decision making in natural resources management. Ecol. Soc. 12 (1), 1-15.

Lynam, T.J.P., 2001. Participatory Systems Analysis: An Introductory Guide. Center for International Forestry Research, Bogor.

Mamdani, E.H., Assilian, S., 1975. An experiment in linguistic synthesis with a fuzzy logic controller. Int. J. Man-Mach. Stud. 7, 1-13.

Melles, Glenn, S., Martin, K., 2003. Urban bird diversity and landscape complexity: species-environment associations along a multiscale habitat gradient. Conserv. Ecolo. 7 (1), 5.

Morancho, A.B., 2003. A hedonic valuation of urban green areas. Landsc. Urban Plan. 66, $35-41$.

Myllyviita, T., Hujala, T., Kangas, A., Leskinen, P., 2011. Decision support in assessing the sustainable use of forest and other natural resources - a comparative review. The Open For. Sci. J. 4 (1), 24-41.

Onkal-Engin, G., Demir, I., Hiz, H., 2004. Assessment of urban air quality in Istanbul using fuzzy synthetic evaluation. Atmos. Environ. 38, 3809-3815.

Ostrom, E., Burger, J., Field, C.B., Norgaard, R.B., Policansky, D., 1999. Revisiting the commons: local lessons, global challenges. Science 284 (5412), 278-282.

Pedrycz, W., Gomide, F., 2007. Fuzzy Systems Engineering: Toward Human-Centric Computing. Wiley-IEEE Press, New York.

Peterson, G.D., Cumming, G.S., Carpinter, S.R., 2003. Scenario planning: a tool for conservation in an uncertain world. Conserv. Biol. 17 (2), 358-366.

Pretty, J.N., Guijt, I., Scoones, I., Thomson, J., 1995. A Trainer's Guide for Participatory Learning and Action Participatory Methodology Series. International Institute for Environment and Development, London.

Reed, M.S., 2008. Stakeholder participation for environmental management: a literature review. Biol. Conserv. 141 (10), 2417-2431.

Robertson, J., Lawes, M.J., 2005. User perceptions of conservation and participatory management of iGxalingenwa forest. S. Afr. Environ. Conserv. 32 (1), 64-75.

Sandström, P., Pahlén, T.G., Edenius, L., Tømmervik, H., Hagner, O., Hemberg, L., Olsson, H., Baer, K., Stenlund, T., Brandt, L.G., Egberth, M., 2003. Conflict resolution by participatory management: remote sensing and GIS as tools for communicating landuse needs for Reindeer Herding in Northern Sweden. Ambio 32 (8), 557-567.

Sayer, J., Campbell, B., 2004. The Science of Sustainable Development: Local Livelihoods and the Global Environment. Cambridge University Press, Cambridge.

Sheil, D., Liswanti, N., 2007. Scoring the importance of tropical forest landscapes with local people: patterns and insight. Environ. Manage. 38 (1), 126-136.

Shepard, R.B., 2005. Quantifying Environmental Impact Assessments Using Fuzzy Logic. Springer-Verlag, New York.

Silvert, W., 2000. Fuzzy indices of environmental conditions. Ecol. Modell. 130 (1-3), 111-119.

Stoll-Kleemann, S., Welp, M., 2008. Participatory and integrated management of biosphere reserves: lessons from case studies and a global survey. Gaia 17, 161-168. 
Tan, K.W., 2006. A greenway network for Singapore. Landsc. Urban Plan. 76, 45-66.

Thompson, C.W., 2002. Urban open space in the 21st century. Landsc. Urban Plan. 60 $59-72$.

Turner, T., 2006. Greenway planning in Britain: recent work and future plans. Landsc. Urban Plan. 76, 240-251.

Twyman, C., 2000. Participatory conservation? Community-based natural resource management in Botswana. The Geogr. J. 166 (4), 323-335.
Warmink, J.J., Janssen, J.A.E.B., Booij, M.J., Krol, M.S., 2010. Identification and classification of uncertainties in the application of environmental models. Ecol. Modelling Softw. 25, 1518-1527.

Zadeh, L.A., 2008. Is there a need for fuzzy logic? Inf. Sci. 178 (13), 2751-2780.

Zadeh, L.A., 2012. Computing with Words. Springer Berlin Heidelberg, Berlin.

Zadeh, L.A., 1965. Fuzzy sets. Inf. Control. 8, 338-353. 